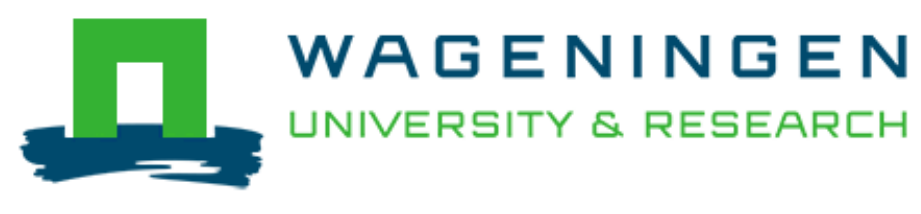

\author{
Greening Flood Protection - An Interactive Knowledge Arrangement \\ Perspective \\ Janssen, S. K. H., van Tatenhove, J. P. M., Otter, H. S., \& Mol, A. P. J.
}

This article is made publically available in the institutional repository of Wageningen University and Research, under article 25fa of the Dutch Copyright Act, also known as the Amendment Taverne.

Article $25 \mathrm{fa}$ states that the author of a short scientific work funded either wholly or partially by Dutch public funds is entitled to make that work publicly available for no consideration following a reasonable period of time after the work was first published, provided that clear reference is made to the source of the first publication of the work.

For questions regarding the public availability of this article, please contact openscience.library@wur.nl.

Please cite this publication as follows:

Janssen, S. K. H., van Tatenhove, J. P. M., Otter, H. S., \& Mol, A. P. J. (2015). Greening Flood Protection - An Interactive Knowledge Arrangement Perspective. Journal of Environmental Policy and Planning, 17(3), 309-331. DOI: $10.1080 / 1523908 \times .2014 .947921$

You can download the published version at:

https://doi.org/10.1080/1523908X.2014.947921 


\title{
Greening Flood Protection-An Interactive Knowledge Arrangement Perspective
}

\author{
STEPHANIE K.H. JANSSEN ${ }^{* * *}$, JAN P.M. VAN TATENHOVE**, \\ HENRIËTTE S. OTTER ${ }^{\dagger} \&$ ARTHUR P.J. MOL** \\ *Scenarios and Policy Analysis, Deltares, Delft, The Netherlands \\ **Environmental Policy Group, Wageningen University, Wageningen, The Netherlands \\ ${ }^{\dagger}$ Subsurface and Groundwater Systems, Deltares, Utrecht, The Netherlands
}

ABSTRACT In flood protection, the dominant paradigm of 'building hard structures' is being challenged by approaches that integrate ecosystem dynamics and are 'naturebased'. Knowledge development and policy ambitions on greening flood protection (GFP) are rapidly growing, but a deficit remains in actual full-scale implementation. Knowledge is a key barrier for implementation. To analyse conditions for the implementation of GFP, a knowledge-arrangement perspective is developed. The knowledge-arrangement perspective is applied on a case study of successful implementation of GFP in the Netherlands, the pilot Sand Engine Delfland, a large-scale $\left(21.5 \mathrm{Mm}^{3}\right)$ sand nourishment project. This project confirms that an integrated knowledge arrangement enables GFP as it allows for multifunctionality. Effectiveness of the integrated arrangement in this project is explained by its 'flexible' nature providing ample design space. This was possible because core values in flood protection and nature were not part of the integrated arrangement. More generally the case study demonstrates the difficulties of implementing GFP in existing mainstream flood protection routines. These are not (yet) geared to incorporate uncertainty, dynamics and multifunctionality, characteristics associated with GFP. The Sand Engine project can be regarded as a 'field laboratory' of physical and institutional learning and an innovation for mainstream flood protection.

KEY WorDs: Flood protection, the Netherlands, nature protection, Sand Engine, policy arrangements

\section{Introduction}

Traditional 'hard' infrastructure for coastal protection against flooding is more and more criticized for being unsustainable and expensive. Damming estuaries and building dikes have unforeseen degrading effects on coastal ecosystem environments (Van Wesenbeeck et al., 2014). The construction costs of artificial structures are high and are accompanied by significant maintenance expenditures

Correspondence Address: Stephanie K.H. Janssen, Scenarios and Policy Analysis, Deltares, P.O. Box 177, 2600 MH Delft, The Netherlands. Email: stephanie.janssen@deltares.nl 
(Smits, Nienhuis, \& Saeijs, 2006). Meanwhile, sedimentation processes change and negatively influence adjacent areas which then also need expensive engineering infrastructure (Airoldi et al., 2005). A promising alternative for conventional coastal protection practices is greening flood protection (GFP). ${ }^{1}$ Such forms of protection, for example, by means of mangroves forests, wetlands or sand nourishments, use natural characteristic and dynamics to mitigate wave energy, stabilize coastlines and serve as flood protection barriers (Gedan, Kirwan, Wolanski, Barbier, \& Silliman, 2011; Van Wesenbeeck et al., 2014). In addition, GFP expands and improves ecosystem environments and can provide substantial coastal ecosystem services, such as fisheries production or carbon sequestration (Hale et al., 2009). GFP is inherently multifunctional, as it combines environmental and social objectives (Barbier et al., 2008; Van Slobbe et al., 2013; Vikolainen, Bressers, \& Lulofs, 2013). Although it is proposed as a sustainable and cost-effective solution in coastal zones prone to changing (climatic) conditions and flooding (Cheong et al., 2013; Hale et al., 2009; Spalding et al., 2013; Temmerman et al., 2013), GFP is not a universal solution as its effectiveness greatly differs among locations and works often well in combination with conventional hard infrastructure (Cheong et al., 2013; Temmerman et al., 2013). Nevertheless it is important in providing low-regret, sustainable and cost-effective solutions for current coastal protection challenges.

GFP significantly differs from conventional flood protection practices. Generally speaking, the latter are static, mono-functional and hard-designed structures aimed at minimizing uncertainty and controlling flood risk, while the former are dynamic, multifunctional and soft measures allowing some uncertainty related to natural variability and dynamics of ecosystems (Naylor, Coombes, Venn, Roast, \& Thompson, 2012; Van den Hoek, Brugnach, \& Hoekstra, 2012). While conventional constructions are fixed and finished after implementation, GFP solutions continue to develop as a form of 'self-design' ${ }^{2}$ (De Vriend, van Koningsveld, \& Aarninkhof, 2014; Mitsch, 2012; Odum \& Odum, 2003). Actual implementation of GFP has proved to be a significant challenge. In fact, up until now implementation remained largely in the form of (small-scale) pilots (De Vriend et al., 2014), while large-scale applications are still absent (Temmerman et al., 2013). Whereas pilots form an important tool in exploring or evaluating innovations and can form the first step towards actual implementation, they also show that GFP has not yet found its way into mainstream flood protection management (Vreugdenhil, Slinger, Thissen, \& Rault, 2010). As knowledge development on GFP is still rapidly progressing (Mitsch, 2012) and policy and politicians continue to express support (Naylor et al., 2012), the most pressing challenge for GFP remains related to the question how to proceed full-scale implementation?

To understand the advancement of GFP, we focus in this paper on the role of knowledge. The multifunctional nature, ecosystem dynamics and unpredictability (uncertainty) in GFP designs require different processes of knowledge production, development and use than commonly applied (Brugnach \& Ingram, 2012; Giebels, van Buuren, \& Edelenbos, 2013). Knowledge should reflect social and ecological complexity (Giebels et al., 2013) and bridge and integrate ecological and flood protection expertise.

The aim of this paper is to understand decision-making on GFP from a knowledge perspective through answering the following question: How can knowledge processes enable or constrain GFP decision-making? To answer this question we gathered empirical data from a GFP project in the Netherlands: the Pilot Sand Engine 
Delfland. This project is a $21.5 \mathrm{Mm}^{3}$ sand nourishment project along the coast integrating ambitions for nature, recreation, flood protection and innovation (PZH \& RWS, 2014). The paper is structured as follows. First, we introduce the analytical framework of knowledge arrangement, used for the case study analysis. In Section 3 , the applied research approach is discussed, followed by a description of the Sand Engine case study in Section 4. In Section 5, the results of the case study are discussed and we finish the paper by concluding upon our findings in Section 6.

\section{Theory: A Knowledge-Arrangement Perspective}

\subsection{Knowledge Literature}

The literature on theories covering the role of knowledge in decision-making is extensive. We categorize the literature on knowledge into two fields: one investigating 'science-policy' interactions and the other investigating interactions among different 'ways of knowing'. This categorization is based on our aim to understand the dynamics of knowledge for GFP.

2.1.1. Science-policy interactions research. The mainstream field of knowledge research is directed to investigate the 'science-policy interface' (Bremer \& Glavovic, 2013; Turnhout, Hisschemöller, \& Eijsackers, 2007). In this field we broadly discern two models that are fundamentally different. The first model is known as the linear model (Röling, 1992). This model represents a conventional understanding of the relation between science and policy building on the 'two-communities' perspective (Caplan, 1979). Science and policy are understood as separate worlds having different languages, values, rewards systems and the like and can be distinguished by means of universally applicable criteria. Moreover, this model assumes a 'science-based fix for all societal problems' (Röling, 1992, p. 46). In this understanding, challenges in the science-policy interface relate to the lack of science-use in policy-making. Solutions are found in improving communication and translation of science to policy. This model is nowadays considered rather outdated and is criticized for being an oversimplification of reality. However, it is still vivid in some fields (McNie, 2007).

The second model is known as the co-production model (Jasanoff, 2004; Wiering, Crabbe, Leroy, \& Arts, 2001). From this perspective, science is considered contextual and the boundaries between science and policy are socially constructed rather than universally applicable (Gieryn, 1983). What counts as scientific knowledge is different for different locations and situations and locally co-produced between science and society in participatory processes (Bremer \& Glavovic, 2013). Besides science, it allows for other forms of knowledge, such as expert, bureaucratic and stakeholder knowledge (Edelenbos, Van Buuren, \& Van Schie, 2011). While in the linear model the process of asking research questions and producing and validating knowledge is considered the domain of 'science' - and thus not relevant for science-policy interactions-in the co-production model this becomes a central matter of concern in such interactions. Risks relate to the development of 'negotiated nonsense' or 'superfluous knowledge' (Van de Riet, 2003) and research is guided by the challenge to produce knowledge that is credible, salient and legitimate (Cash et al., 2003). Solutions are found in new forms of knowledge production, including practices of participation, integration, learning 
and negotiation between scientists and policy-makers (Van Kerkhoff \& Lebel, 2006).

In summary, whether the boundaries of science and policy are considered universal and fixed (as in the linear model) or negotiated and contextual (as in the second model) the common denominator in both models is a focus on the relation between science and policy. The multiplicity of knowledge in the co-production model aligns with the knowledge challenge in GFP (Bremer \& Glavovic, 2013; Coffey \& O'Toole, 2012; O'Toole \& Coffey, 2013). The co-production model, however, does not deal with the interactions and potential conflict between different science-policy arrangements, while we consider this a main concern in GFP. For that, we turn to the literature on 'ways of knowing'.

2.1.2. Ways of knowing research. In an upcoming field of research the focus on science-policy interaction has shifted towards the idea of multiple 'ways of knowing' (WoKs) (Feldman, Khademian, Ingram, \& Schneider, 2006; Van Buuren, 2009) or knowledge coalitions (Van Buuren \& Edelenbos, 2004). The WoK perspective puts the interactions among different WoKs central, as these are considered more important for (competing) knowledge claims and use than the interactions between science and policy (Van Buuren \& Edelenbos, 2004). Coffey and O'Toole (2012) show how such an understanding is particularly warranted in assessing coastal dynamics given their complexity, conflict and multiple knowledge forms. Frequent and ongoing interactions within a WoK (Dewulf, Brugnach, Termeer, \& Ingram, 2013) and disciplinary congruence among scientists and policy-makers institutionalize relations in a single domain (such as flood protection) (Edelenbos et al., 2011). As a result, science-policy interactions within that domain are not perceived as problematic because forms of knowledge to define problems and solutions are framed in similar ways in science as in policy. Rather, knowledge conflicts occur at the boundary of different WoKs. Hence, the simultaneous existence and interaction of multiple WoKs is explicitly recognized. The interaction processes among WoKs are an incentive for processes of meaning-making, where meanings converge or reinforce each other (Lejano \& Ingram, 2009). WoKs are very dynamic and in continuous flux (Lejano \& Ingram, 2009). As WoKs are inherently dynamic so is knowledge in WoKs. 'Knowing' as opposed to knowledge is emphasized: 'a [WoK] can be distinguished from knowledge in that it emphasizes the active dimension of knowing a problem' (Schneider \& Ingram, 2007, p. 4, emphasis added). Knowing implies a focus on the process rather than on static outcomes and includes processes of knowledge production and gathering as well as meaning-making of knowledge. The main research questions then cover the understanding of the dynamics within WoKs, interactions between WoKs and the crossing of boundaries among WoKs. Boundary management is often introduced as a solution (cf. Dewulf et al., 2013; Lejano \& Ingram, 2009; Muñoz-Erickson, 2013; Van Buuren \& Edelenbos, 2004) but is applied in a different way from boundary management between science and policy, as introduced by Gieryn (1983).

In the literature different concepts are used for similar ideas-WoKs, knowledge coalitions, knowledge-actions systems-emphasizing different research traditions and operationalizations. In defining WoKs, Schneider and Ingram (2007) considered meaning-making the result of interactions among objects, including artefacts, reports, stakeholders and more. In contrast, knowledge coalitions, as introduced by Van Buuren and Edelenbos (2004), are primarily defined from an 
actor perspective. Dewulf et al. (2013) include a structural perspective by linking networks and frames in explaining the role of knowledge. A drawback of the WoK research is that the concept is not yet fully crystallized. ${ }^{3}$

\subsection{Analytical Framework for Understanding Knowledge for GFP}

The multifunctional nature of GFP explicitly draws attention to the integration of knowledge from different domains. Domains are often strongly institutionalized and characterized by frequent internal interactions. This is especially true for the Dutch flood protection domain, building upon a long tradition of protection against flooding and close interactions between flood protection science and coastal management (Van Koningsveld \& Mulder, 2004). Moreover, the coastal zone is characterized by fragmentation among policy domains (Van Buuren, De Bruin, Zweegman, Becker, \& Raadgever, 2010). The main knowledge challenge of GFP is thus not expected to lie between science and policy within domains, but rather with interactions among domains. We therefore build upon insights of the WoK research. As concepts used in this field lack operationalization, preciseness and thus potential as analytical framework for case study analysis, we introduce a new approach allowing for a more structured and systematic analysis of interaction among WoKs.

2.2.1. Building upon the policy arrangement approach towards knowledge arrangements. To construct our model of knowledge arrangements we employ the policy arrangements as developed by Van Tatenhove, Arts, and Leroy (2000). This analytical framework is especially useful to unpack the policy side of what we will label a knowledge arrangement. The policy arrangement framework has mainly been applied to analyse stability and change in the environmental policy domain. A policy arrangement is defined as the temporary stabilization of the organization and substance of a policy domain at specific level of policy making' (Van Tatenhove et al., 2000, p. 54) and makes up four dimensions: (1) actors and coalitions, (2) rules and regulations, (3) discourses and (4) resources. The dimensions are interrelated and dynamics result from this as 'a change in one of the dimensions is likely to lead to changes also in one or more of the other dimensions' (Liefferink, 2006, p. 66).

The policy arrangement framework has demonstrated its applicability in a broad array of research domains (including water management, spatial planning, nature conservation, marine infrastructure, road infrastructure). Yet this framework has not been designed to analyse ways of knowing. Understanding processes of knowing-including producing, interpreting and using knowledge-is not conceptualized nor emphasized in the policy arrangement framework. Therefore we (1) re-interpret and redefine the dimensions of the policy arrangement as to allow for understanding processes underlying knowing (Table 1) and (2) relate this redefined policy arrangement to the knowledge base that is continuously being developed and used. Following Hommes (2008) and Hommes, Vinke-de Kruijf, Otter, and Bouma (2009) we define a knowledge base as a collection of knowledge sources (i.e. research reports, models, data, practical experiences, etc.) that have been made explicit and are related to a specific policy arrangement. The (redefined) policy arrangement and its interactions with the knowledge base together make up what we refer to as the knowledge arrangement (Figure 1). A knowledge arrangement is then defined as the dynamic interdependent constella- 
Table 1. Re-interpretation of the dimensions of the policy arrangement to allow for understanding processes of knowing

\begin{tabular}{|c|c|}
\hline Dimension & Interpretation of the dimension for the understanding processes of knowing \\
\hline Discourse & $\begin{array}{l}\text { The discourse dimension captures the views and narratives of the actors } \\
\text { involved regarding a certain issue and the required and appropriate } \\
\text { knowledge sources, methodologies, knowledge actors, etc. }\end{array}$ \\
\hline $\begin{array}{l}\text { Actors and } \\
\text { coalitions }\end{array}$ & $\begin{array}{l}\text { The actors and coalition dimension refers to the actors involved in the policy } \\
\text { arrangement and how these relate to one another. These include actors } \\
\text { involved in knowledge processes }\end{array}$ \\
\hline $\begin{array}{l}\text { Rules and } \\
\text { regulations }\end{array}$ & $\begin{array}{l}\text { Rules and regulations refer to the formal and informal rules that structure action } \\
\text { of actors and the development, interpretation and use of knowledge }\end{array}$ \\
\hline Resources & $\begin{array}{l}\text { The resources dimension relates to the (division of) resources and related power. } \\
\text { Resources are, for example, finances, knowledge sources, knowledge } \\
\text { development capabilities or political and decision-making power }\end{array}$ \\
\hline
\end{tabular}

tion of a knowledge base and the (redefined) policy arrangement within a specific domain.

2.2.2. Interacting knowledge arrangements. Following our theoretical approach and empirical notions on GFP in the coastal zone, GFP becomes a matter of interacting knowledge arrangements (Figure 1). Interaction can have multiple outcomes: separation, cooperation, integration and unification (Janssen, Mol, Tatenhove, \& Otter, 2014). Our presupposition is that an effective implementation of GFP requires integration among sectoral/domain-specific knowledge arrangements. Authors have argued for comprehensive governance approaches as opposed to sectoral governance (Halpern, McLeod, Rosenberg, \& Crowder, 2008; Katsanevakis et al., 2011), have demonstrated the impeding nature of multiple discourses on knowledge for GFP decision-making (Nursey-Bray et al., 2014) and have argued for interdisciplinary knowledge research and design for nature-based coastal management (Naylor et al., 2012; Van Wesenbeeck et al., 2013).

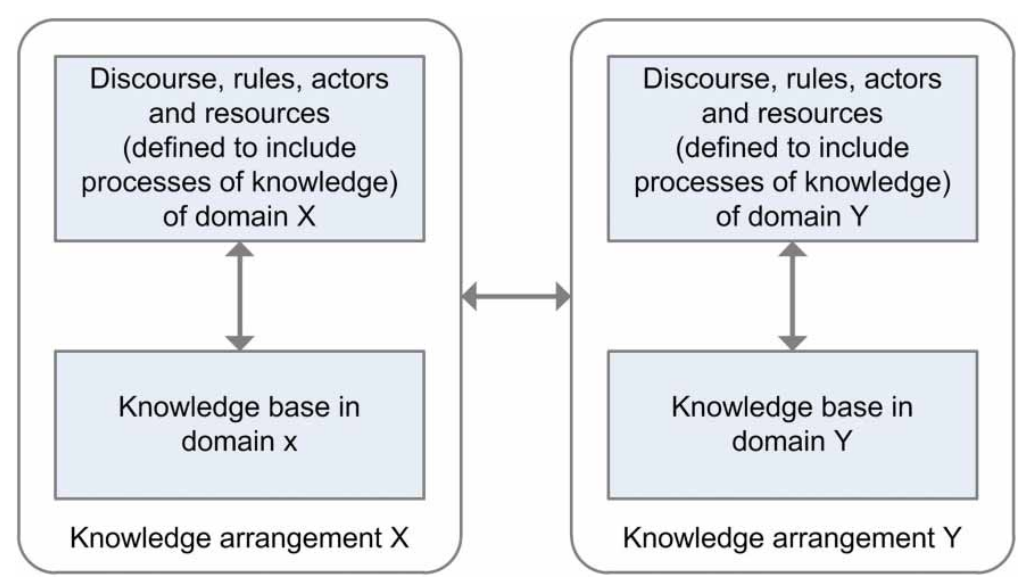

Figure 1. Schematic overview of interaction among knowledge arrangements. A knowledge arrangement is build-up of the re-interpretation of the policy arrangement (i.e. explicitly recognizing knowledge processes) the knowledge base. 
In the literature, integration is defined in multiple and varying ways (Derkzen, Bock, \& Wiskerke, 2009; Van Kerkhoff, 2005). We build upon the general notion by Van Kerkhoff (2005, p. 458): 'integration indicates bringing disparate elements into a whole'. Applied to knowledge arrangements, integration refers to the emergence of a new (temporary) knowledge arrangement for a particular issue on a particular place. Such an integrated knowledge arrangement includes an actor coalition involving actors from the original arrangements, a collective set of agreements, a collective discourse in the actor coalition, resources originating in both original knowledge arrangements and collective developing, interpreting and using knowledge. Integration is often location and time specific and not a permanent state. Integration can take place at the project level while leaving sectoral knowledge arrangements at the national level unaffected. Moreover, the integration can disappear when the project ends. Integration differs from cooperation, as cooperation does not involve collective discourses, rules, knowledge development, resources or actor coalition. With cooperation these dimensions remain founded in separate knowledge arrangements, while communication and mutual informing is employed. Integration differs from unification in that the original knowledge arrangements continue to exist beyond the time- and location-specific boundaries of the integration.

\section{Research Approach}

In order to study interacting knowledge arrangements and its outcome in the context of GFP projects we analysed the project Pilot Sand Engine Delfland (hereafter Sand Engine). This single case study approach enabled in-depth analysis of knowledge arrangement interactions. We selected the project halfway 2009 based on three criteria. First, the objectives of the project integrated multiple functions, including flood protection and nature. Second, GFP principles were used in the designs of the Sand Engine which are the use of natural dynamics, such as wind and waves for sand transport, and natural dune growth. Third, we gained full access to the project in terms of meetings, interviews and project documents.

For data collection we used participatory observations, interviews (12x see appendix), and studied project documentation, including all minutes of meetings of the project team and the steering committee, internal notes and knowledge documents. The interviews were semi-structured and informed by a list of about 10 questions that guided the interviews. The interviewees were selected based on their position in the project and their home-institutions. Some interviewees were suggested by earlier interviewees. Two well-informed project participants were consulted on earlier versions of this paper: one provincial respondent and one Deltares respondent. The latter had a history in Rijkswaterstaat (RWS) and had been working on Sand Engine ideas since 2005.

The data were structured by means of the theoretical framework of interacting knowledge arrangements using the five dimensions of the knowledge arrangement. We focused on the interaction between the flood protection and nature domains ${ }^{4}$ (the 'foundational' domains) and the outcome of this interaction in the Sand Engine project. Addressing the sectoral domains is crucial for understanding possible integration (Derkzen et al., 2009). We start our analysis from the foundational knowledge arrangements after which we continue with the Sand Engine knowledge arrangement. We address each dimension separately, zooming into the discourses applied, the actors in the project, their relations, 
resources, the rules and regulations determining the process and the knowledge base resulting from this. In the analysis of the dimensions in the sand engine we analyse how these are related to the foundational arrangements. Our analysis starts from the beginning of the project until the decision for the preferred design in February 2010. The emphasis is on the planning phase (April 2008-February 2010), as in this period the main knowledge development and decision-making developed.

\section{Case Study: Pilot Sand Engine Delfland}

Two parties, RWS $^{5}$ and the province of Zuid-Holland (PZH), joined forces in 2007 to work on the realization of the 'Sand Engine'. RWS had been working on ideas for large-scale nourishments as part of their responsibility for coastline maintenance. $\mathrm{PZH}$, dealing with increasing spatial pressure and a significant lack of green recreational areas, had an interest in expanding their land-area seawards. The implementation process of the Sand Engine can be regarded as quite successful: after signing an 'ambition' agreement among nine interested stakeholders in April 2008 in which the goals and ambitions of the project were agreed upon, it took about 3.5 years, without significant delays, until the Sand Engine was fully realized (Figure 2).

The Sand Engine is a multifunctional and large-scale sand nourishment project. It was constructed as a hook-shaped peninsula piling up $21.5 \mathrm{Mm}^{3}$ of sand. It has an above water area of $75 \mathrm{ha}$, and is attached to the South-Holland coastline over a length of $2 \mathrm{~km}$. The bulk of sand is expected to disperse along the coastline and dunes in a natural manner and disappear over a period of about 20 years (Stive et al., 2013). This approach serves multiple functions: it con-

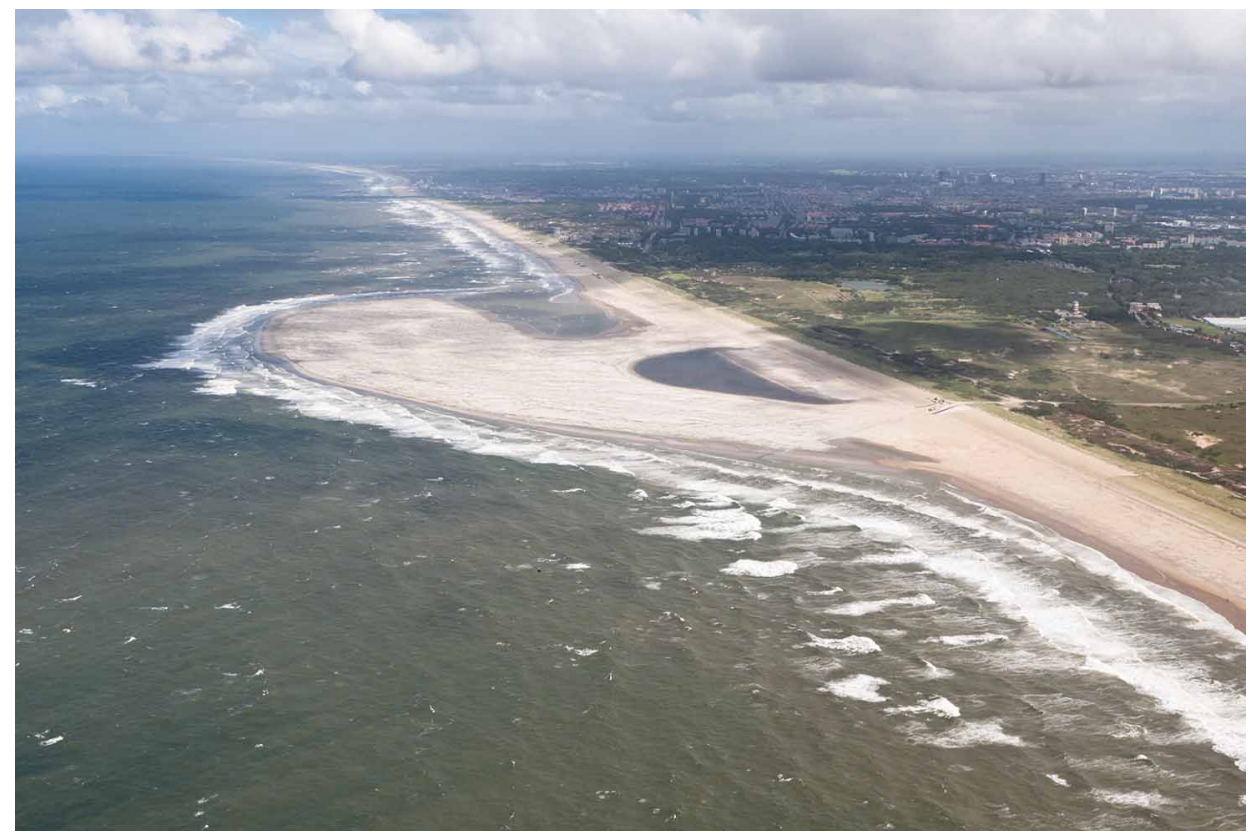

Figure 2. Aerial view of the Sand Engine just after completion (9 August 2011 ®Zandmotor). 
tributes to flood protection by compensating for sand losses from erosion processes along the coastline; it creates temporary recreational and natural areas; and it contributes to natural dune formation. The project was set up as a 'pilot' —or put in different words: an experiment-and contributes to knowledge development and learning. The Sand Engine 'experiment' is being monitored intensively and first observation show that the nourishment is indeed feeding the adjacent coasts (Stive et al., 2013).

In the following sections we describe the knowledge arrangements of flood protection, nature and the Sand Engine project by elaborating on the actors, discourses, rules, resources and knowledge base (a summary is provided in Section 4.4, Table 1). Such an elaboration allows us to understand how flood protection and nature were combined in this project and what conditions allowed for implementation of GFP decision-making.

\subsection{Flood Protection Knowledge Arrangement}

Part of the Dutch flood protection policy consists of the maintenance of the coastline. ${ }^{6}$ Coastline maintenance is organized to counteract structural coastal erosion by means of sand nourishments. It involves close monitoring of the coastline and nourishing sand at those locations where erosion occurs. Yearly, $12 \mathrm{Mm}^{3}$ is nourished along the coastline divided over multiple smaller nourishments. The Sand Engine directly affects coastline maintenance: a large amount of sand is added to the coast and extends the coastline. It is a new and innovative strategy, mostly for the scale used.

The objective of coastline maintenance is: 'the sustainable preservation of safety against flooding and of values and functions in the dune area' (V\&W, 1990). The position of the coastline in 1990-defined as 'Basic Coastline' (BKL)governs the execution of sand nourishments. Nourishments for other functions than flood protection (e.g. recreation) are more expensive and poorly articulated, caused by fragmented policy fields (Lubbers et al., 2007; Mulder, Hommes, \& Horstman, 2011; Van Buuren et al., 2010).

Three actors prevail in coastline maintenance: RWS, the Directorate General Water (DGW) and Deltares. Both RWS and DGW are part of the Ministry of Transport, Public Works and Water Management (V\&W). RWS has a central position being responsible to execute the coastline maintenance policy. DGW is responsible for water policy, including coastline maintenance. Deltares is a research institute working among others in the field of coastal morphology and having a leading position in Dutch coastal research programmes. Deltares is preferred knowledge supplier for the ministry. Other stakeholders are informed about coastline maintenance policy and works, but there is only limited decision-making involvement of local governmental actors, such as provinces and municipalities, non-governmental organisations (NGOs), other research institutes and users of the coast in designing and executing the coastline maintenance policy. ${ }^{7}$

The discourse in coastline maintenance is dominated by the principle that flood protection and maintaining functions in the coastal area requires keeping the coastline at BKL position. Structural loss of land to the North Sea, either resulting from erosion or sea-level rise, should be prevented. Hence, the discourse is focused on 'preservation' of the coastline, rather than 'development'. Coastline maintenance, in particular the use of BKL and sand nourishments, is generally regarded a success and goes largely uncontested (Lubbers et al., 2007; Van 
Koningsveld \& Mulder, 2004). Climate change and associated sea-level rise have raised discussions on the nourishment budget and the need for further coastline extension beyond BKL. These discussions also drew attention to the use of larger and innovative types of nourishments other than the beach and foreshore nourishment that are currently common (Giardino, Mulder, Ronde, \& Stronkhorst, 2011) such as the Sand Engine (interview DGW representative, 10 February 2010).

Rules and regulations in coastline maintenance show stable patterns with only gradual changes since 1990 (Van Koningsveld \& Mulder, 2004). A focus on longterm coastline maintenance $(\mathrm{V} \& W, 2000)$ resulted in increasing the nourishment budget from 6 to $12 \mathrm{Mm}^{3}$ yearly. In 2007, water policy addressed the need for innovation in coastline maintenance, with an explicit reference to the Sand Engine (V\&W, 2007).

Administrative and financial resources lie within the Ministry of V\&W. DGW provides RWS an assignment and financial resources to execute coastline maintenance policy. RWS and Deltares have key roles in knowledge development, while DGW trusts upon the expertise of RWS.

The knowledge base can be split into two categories. First, there is generic knowledge on coastal, mainly morphological, processes with a focus on understanding system behaviour. Field monitoring, data analysis and numerical modelling are important research methods. Second, there is context-specific knowledge. Exact predictions of morphological processes are difficult and therefore experiences gained over the last 20 years on the local behaviour of the coastline and nourishments are of crucial importance. Both knowledge are intended to contribute to the (cost-) effectiveness of nourishments. The debate on innovative and large-scale nourishments resulted in some exploratory exercises, among others a report exploring the possibilities for and introducing the concept 'Sand Engine' (RWS, 2005).

\subsection{Nature Knowledge Arrangement}

Nature policy works in two ways. First, nature is found in protected sites. Devolution of nature policy resulted in a central role for regional actors: provinces are responsible for management of sites and local actors and environmental NGOs are involved in the execution and monitoring of site management plans (Gerritsen et al., 2009). National government and the European Union define the terms. The discourse is dominated by a focus on protection and preservation of the nature sites, which is often specified in terms of species or habitats. These are embedded in strong legislative frameworks of 'Natura2000'8 and the National Ecological Network (EHS), which constitute the rules for protected sites. Provinces hold decision-making power and financial resources when it comes to execution of this nature policy. Traditionally, the nature policy field builds upon scientific insights from ecology and ecologists (Bogaert \& Gersie, 2006). Besides ecologists, managers possess site-specific knowledge of nature protection sites. Inspired by the legislative framework, the knowledge base is directed towards species, habitats and ecological processes, and related enabling and constraining conditions. The Sand Engine is bordering the Natura2000 site Solleveld and Kapittelduinen. The nature objective of the project however was not related to this site, it served as a boundary condition though. ${ }^{9}$

In a second understanding of nature policy, nature is part of the living environment and spatial planning policy. In contrast to nature site protection, spatial plan- 
ning is inherently a multi-actor and multi-interest affair as it concerns the allocation of multiple functions. Nonetheless the province is also a central actor in spatial planning. The discourse on nature in spatial planning and outside protected sites is merely oriented towards supporting recreational functions or improving general attractiveness of an area without concern for particular species or habitats. The representation of nature interests in this battle of competing interests is often poor, originating from a lack of financial resources and regulative support outside protected areas. A governmental authority as 'owner' of nature interests outside the protected sites is often lacking (Van Buuren et al., 2010), while NGOs have limited power in decision-making and are frequently forced into an opposing role. The Sand Engine nature objective should be understood as part of the spatial planning ambitions of PZH to increase 'recreational green' in the coastal zone and to develop this area. A knowledge base supported this ambition. Research reported a shortage of 6000 ha for recreation in the coastal zone (Abma \& Berkers, 2006). Moreover the possibilities for integral coastal development and extension had been explored suggesting that integral coastal development is important for environmental quality of the area (AdviescommissievoordeZuid-Hollandsekust, 2006). This advice led $\mathrm{PZH}$ to install a committee on coastal development to further explore these possibilities. The committee represented a broad range of stakeholders, including ministries, municipalities and the waterboard (a regional water quality and quantity management agency). This committee forms the origin of the Sand Engine project organization.

\subsection{Sand Engine Knowledge Arrangement}

In the beginning of 2008, a platform supporting innovation and led by the Dutch prime minister asked PZH to develop a plan for the 'Sand Engine'. Moreover, the ministry of V\&W made a budget available for the project. The ambition agreement signed in April 2008 among nine stakeholders marked the start of the planning phase. This phase of the Sand Engine constitutes a period of developing design alternatives and a period of selecting, optimizing and deciding upon the preferred design. Four design alternatives were developed: an underwater nourishment, an island, hook-south and hook-north (PZH, 2010). From these designs hook-north was selected as the preferred design. The underwater nourishment was not a visible solution and did not yield any recreational options (both important criteria for $\mathrm{PZH}$ ). The island was considered too risky for recreation. Hook-south could have negative impact on existing recreation and interfered with a local pumping station. And thus Hook-north was most desirable: it did not disturb any ongoing activities; yielded some (and not too much as this would lead to infrastructural problems) recreational facilities; and was both visible and accessible (Figure 3).

Actors and their interests were broadly represented in the Sand Engine project. In the organization of the project up to 15 different actors were involved. The parties that signed the ambition agreement formed the core: the Ministries of V\&W (representing both DGW and RWS), Housing, Spatial Planning and the Environment (VROM) and Agriculture, Nature and Food Safety (LNV), PZH, three municipalities, the waterboard and an environmental NGO. PZH and RWS were initiators of the project. PZH was leading the planning phase, initiated design workshops and commissioned (research) reports to consultants. RWS was leading during project execution (2010-2011), while in the planning phase their 

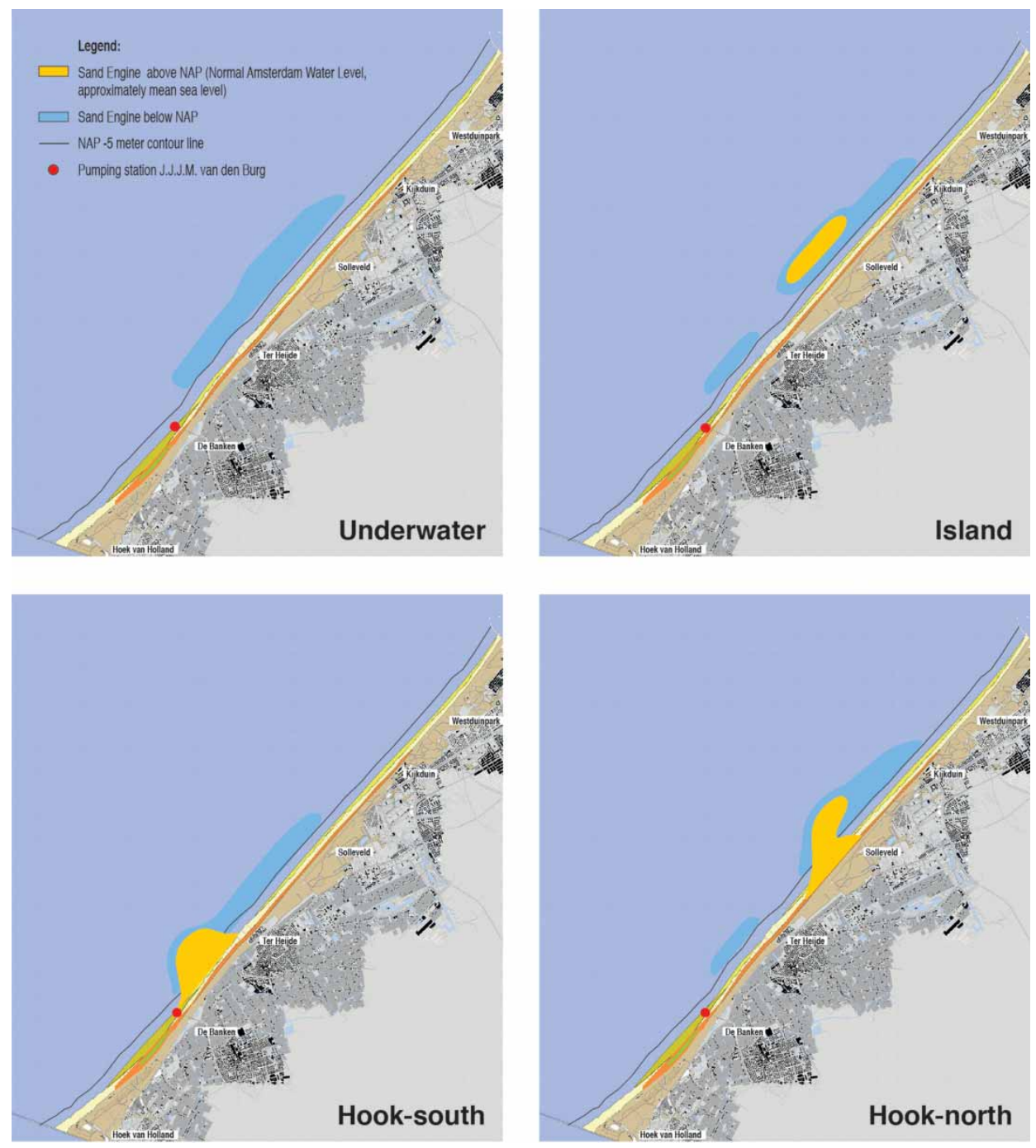

Figure 3. Overview of four design alternatives. Clockwise, starting upper left corner: underwater, island, hook-south and hook-north (PZH, 2010).

role was much less prominent. Knowledge parties were also part of the project organization: Delft University of Technology, Deltares, innovation programme Ecoshape and consultancy firms. During the course of the project, new actors entered and left the project organization. For example, drinking water company DUNEA was included in the project team when effects of the Sand Engine on groundwater appeared important.

For PZH, the development of recreational green and the visibility of the Sand Engine were most important. Among others, this led to the hook-north as the preferred design. The interest of RWS for the Sand Engine was threefold: knowledge development for long-term coastline maintenance, as executor of the project and as manager of the coastline (interview RWS representatives, 11 March 2010). During the planning phase RWS was reticent and critical towards the preferred design. From an RWS perspective, hook-north was relatively expensive (an under- 
water nourishment would be cheaper), unpredictable and inefficient. DGW was less critical and emphasized the innovation potential and also the cost-effectiveness of placing $21.5 \mathrm{Mm}^{3}$ at once (this approach, in combination with the tender strategy led to a very low sand price). The three involved municipalities and the waterboard mainly aimed to prevent negative effects of the Sand Engine, for example on local recreation, shipping or groundwater levels. Nature interests were poorly represented in the project organization, despite enthusiasm of organizations such as the World Wildlife Fund and the Ministry of LNV.

The Sand Engine is considered an innovative, natural and multifunctional concept, set up as an experimental pilot. Innovation relates in particular to the scale of the nourishment and the multifunctional approach. It meets the need for new and innovative concepts to handle the future challenges for coastal development (this need is expressed in a number of policy documents and advises, for example, the Watervisie (V\&W, 2007) and report of the Deltacommittee (Deltacommissie, 2008)). The Sand Engine is, in particular in external communication (nationally but also internationally the sand engine is presented as 'building with nature' solution, for example at the World Expo in Zaragoza Spain 2008 and the World Water Forum 2009 in Istanbul), presented as a 'building with nature' solution to coastal development combining flood protection with nature and recreational development. Its mechanisms are natural, as the sand is dispersed along the coastline by means of wind and waves. The announcement for a public meeting provides a good summary of the employed discourse (PZH, 2009):

The Sand Engine is a large amount of sand that will be located in front of the Delfland Coastline. This part of the coast will grow naturally. As a result, more space for nature and recreation is created as well as a contribution to long-term flood protection. The Sand Engine is an innovative pilot, from which knowledge is gained for coastal development, building with nature, and innovative means for coastal reinforcement needed for climate change.

Rules and regulations guiding the decision-making process consist of project objectives, legislation and policy objectives. The project objectives are among others laid down in the ambition agreement and express the intention to combine flood protection, nature, recreation and innovation. These are however described in a general way and are not prioritized. For example, the meaning of 'nature' was not specified in terms of the type, size or location aspired and also 'flood protection' objectives were not specified. The implicit assumption was that any dune growth would contribute to safety and also to nature. Prevailing legislation and policy objectives for both flood protection and nature did not further specify the design, but functioned as boundary conditions: coastline (BKL) erosion and negative impact on the Natura2000 site were to be prevented. The environmental impact assessment (EIA) procedure formed the basis for acquiring necessary permits.

The most prominent resources in the project were decision-making power, budget and knowledge. Budget and knowledge were shared. The Sand Engine was financed by the Ministry of V\&W for $83.3 \%$ and by province PZH for $16.7 \%$, providing these actors preferential positions in the project. The ministerial budget for the Sand Engine was not taken from the coastline maintenance budget. Rather an 'innovation' fund was made available for the Sand Engine. Knowledge was a collective resource throughout the process. Knowledge products-whether workshops, designs, research reports or EIA documents-were prepared, dis- 
cussed and assessed collectively in the project team. The central position of PZH as leading in the planning phase provided this actor decision-making power.

The development of the knowledge base differed between the designing period (i.e. developing the four design alternatives) and the decision-making and design optimization period (i.e. selection and optimization of the preferred alternative). In designing the four alternatives for the Sand Engine, knowledge development was very interdisciplinary. A multi-disciplinary team of ecologists, morphologists and engineering experts executed a preliminary design study. In workshops, a broad representation of actors and experts jointly developed designs for the Sand Engine. The resulting four designs met the multiple objectives of the project. Also in this phase, morphological developments of the designs were estimated based on computer modelling, including a new software tool integrating ecological parameters. In working towards a decision for the preferred design and in optimizing this design, the focus shifted to the singular effects of the Sand Engine: on ecology, on flood protection, on recreation or other. Knowledge development, informed by the EIA procedure to assess separate effects of the design, continued in a more mono-disciplinary manner. Workshops were organized per discipline for example among morphological experts or ecological experts and reports were developed per discipline. Hence optimizations that synchronized objectives as was done in designing the Sand Engine alternatives did not take place. However, an important exception is the assessment of knowledge. This happened in the multi-stakeholder project team throughout the project. As a consequence, all documents were assessed from multiple perspectives and disciplines.

\subsection{An Integrated Knowledge Arrangement}

The knowledge arrangement on nature and the knowledge arrangement on flood protection became connected around the topic of large-scale sand nourishment. This shared interest led to a knowledge arrangement that integrated the two foundational knowledge arrangements: the Sand Engine knowledge arrangement. This knowledge arrangement is a temporary and location-specific construction. Integration can be found in all five dimensions of the knowledge arrangement: an actor coalition emerged representing actors from both arrangements; there is a collective discourse identifiable connecting the four objectives of the project; a collective set of rules guiding the process and content of the project is agreed upon by actors (a.o. laid down in the ambition agreement); an integrated knowledge base is developed and assessed in an integrated way by means of an interdisciplinary project team, and financial resources from both foundational knowledge arrangements substantiated the project. Some aspects however in optimization and selection of the preferred design show features that we do not regard as integrated. Informed by the EIA procedure, assessment and optimization of the designs was dealt with by looking at separate aspects and knowledge development on these separated aspects. The knowledge arrangements are summarized in Table 2.

\section{Understanding Integration of Knowledge Arrangements}

Based on the knowledge arrangements in the Sand Engine, we analyse factors that enabled integration of knowledge arrangements (in Section 5.1) and that enabled GFP (in Section 5.2). 
Table 2. Summary of three knowledge arrangements: flood protection, nature and Sand Engine

Flood protection

\begin{tabular}{ll}
\hline Actor & RWS, DGW, Deltares \\
Discourse & $\begin{array}{l}\text { Coastline maintenance, } \\
\text { preservation of BKL, cost- } \\
\text { effectiveness, innovation }\end{array}$
\end{tabular}

\section{Rules and}

regulations

Stable processes of decision-

making and legislation over last 20 years

Policy documents supporting Sand Engine like ideas

Resources

Coastal maintenance responsibility and budget by RWS

Policy development by DGW

Knowledge base

\section{Nature}

Sand Engine (designing, decision-making and optimization)

$\mathrm{PZH}$ as the central actor

Other (regional) actors such as

municipalities, e-NGOs and ministries

Protection of species and habitats within protected sites

Need for recreational green in integral coastal zone development

\section{Nature sites}

Spatial planning policy

PZH responsible and resources for nature policy execution

PZH decision-making power in chairing committee for coastal development

For nature sites (ecological), knowledge on species, habitats and enabling processes and conditions

Reports on recreational green and integral coastal zone development and extension
Broad coalition of actors in project organization: PZH, RWS, municipalities, NGO's Consultants, Deltares, Universities. Easy entry and exit of actors during the project

Innovation

\section{Natural}

Multifunctional

Building with nature

Pilot

Project objectives in ambition agreement, not specified or prioritized

BKL and Natura2000 as boundary conditions

For decision-making: EIA report and formal procedures

Decision-making power with $\mathrm{PZH}$

Budget shared among V\&W and PZH

Knowledge shared throughout the process

Multi-disciplinary workshops and reports

Four design alternatives

Modelling of designs integrated beach dune model development, knowledge assessment in project team

For decision-making and optimization: reports and workshops on singular effects, EIA report 


\subsection{Enabling Integration Among Nature and Flood Protection Knowledge Arrangements}

Factors enabling integration among knowledge arrangements are found in the developments that preceded integration and the type of integration.

5.1.1. Developments preceding integration. In preparatory developments for the Sand Engine we find two grounds for integration (Huitema \& Meijerink, 2010). First, there is a shared interest in the Sand Engine as a solution. In both foundational knowledge arrangements, ideas for multifunctional, large-scale sand nourishments popped up, albeit for different reasons. For coastline maintenance, climate change and sea-level rise induced a debate on long-term coastal protection. A need emerged for increasing nourishment volumes, extending the coastline and development of innovative methods. In the nature knowledge arrangements, an extension of the coastline was considered as a solution for the shortage of recreational green in the coastal zone of the province of SouthHolland. The Sand Engine is a solution for different problems, and thus a shared interest. Second, there is resource interdependency among the two arrangements. Actors from both arrangements recognize the value of the resources of the other arrangement representatives, providing a potential for collaborative solutions to emerge (Gray, 2004). PZH was in charge of decision-making by chairing the steering committee and acquiring the assignment of the PrimeMinister for developing a plan. The ministry of V\&W had budget available for the project.

5.1.2. Flexible integration. Integration was established between flood protection and nature knowledge arrangements. However integration was flexible and moreover core values of the foundational knowledge arrangements were excluded. Both characteristics of integration were central to the success of this integrated knowledge arrangement.

Integration is typified as flexible in particular because the project objectives allowed for various interpretations and the actor coalition was adaptive. The objectives were defined rather generally (in contrast to BKL, species or habitats as used in the foundational knowledge arrangements), making specific assessment impossible. This strategy made finding synergies among functions quite easy and provided ample design space for the Sand Engine. The actor coalition changed-actors left and entered the coalition-depending on the matters on the agenda and their interests. In addition, core values were excluded from the integration. Core values are those elements of knowledge arrangements that are deemed essential, such as the BKL in the flood protection arrangements or the protected species in the Natura2000 site. The design of the Sand Engine and even more its location illustrate this, in particular for the flood protection core values. The Sand Engine was located where it 'can harm the least' (interview Deltares representative, 19 April 2010). The dunes at the location of hook-north had just been reinforced, which made additional flood protection somewhat redundant. Hook-north was complemented with additional nourishment to prevent possible erosion of the BKL in northward direction. These measures assured that any negative impact on ongoing coastline maintenance was prevented. Moreover, the annual budget for coastline maintenance was not used for the Sand Engine as 'effects for maintenance of the coastline are unknown' (interview DGW representative, 10 February 2010). 
Flexible integration and the exclusion of core values strongly contributed to the success of the Sand Engine: nothing essential was at stake, not within the project (the objectives are too vague to critically assess) nor outside the project (as core values are protected). This construction prevented possible conflicts or discussion about trade-offs that could possibly have impeded swift implementation. On top of this, the project was a pilot. Everything not accounted for in the project or uncertain could later on be explained by the argument that the project was an experiment.

\subsection{Enabling GFP: Space for Design}

The integrated Sand Engine arrangement enabled GFP by allowing for natural dynamics and its unpredictability and multifunctionality in the design and generating support for it in decision-making. These conditions directly contribute to implementation of GFP. The multifunctional character of the project required combining multiple perspectives and values that should be reflected in an inclusive process of knowledge production (Brugnach \& Ingram, 2012). Such inclusive processes are different from more traditional processes of knowledge production in terms of knowledge type and involvement of stakeholders (Brugnach \& Ingram, 2012). Here we consider the relation between the creation of the knowledge base and policy arrangement in the Sand Engine knowledge arrangement and extract factors that enabled integral GFP knowledge development and support.

The entire actor coalition was involved in the developments of Sand Engine designs by means of workshops. Besides, all knowledge documents were discussed and assessed in the project team. This approach makes the knowledge base inherently relational (Brugnach \& Ingram, 2012). It allowed for including different types of knowledge and different values, representing the different views on the Sand Engine. In addition, face-to-face interaction that happened in both the workshops and the project meetings are important for the transfer and building of tacit project knowledge (Koskinen, Pihlanto, \& Vanharanta, 2003) as are intensive interactions (Vinke-De Kruijf, Hulscher, \& Bressers, 2013).

The discourse of the Sand Engine represents the various values in the project and at the same time is open for multiple interpretations. In addition, it allowed for uncertainties that are inherent in GFP designs by explicitly presenting the Sand Engine as an innovation and as a pilot. By this, the uncertain aspects of the GFP designs were lightly accepted (later on in the process, management and monitoring plans were developed handle uncertainties).

The rules in the project directly affected the development of the knowledge base. The jointly agreed upon project objectives guided the design development. The unspecified formulation provided ample design space for developing the Sand Engine design. It also prevented conflicts (and delays) or the need for trade-offs among goals. In design optimization and selection, the development of knowledge was influenced by boundary conditions and EIA effect assessment. This entailed, for example, investigating the effects on the bordering Natura2000 site and on morphological developments to predict coastline development. The formal rules steered knowledge development towards a more mono-disciplinary mode.

Overcoming disparities in power is one of the main challenges towards creating inclusive and integral knowledge (Brugnach \& Ingram, 2012). In the Netherlands, the flood protection domain and related knowledge is deeply 
institutionalized and provided with ample resources, in contrast to a less wellresourced and organized nature domain (Van Buuren et al., 2010). In the Sand Engine project, however, the differences in power were less extreme. PZH controlled decision-making in chairing the project, while the role of RWS was downsized and levelled with other project participants. This downsized the dominance of flood protection knowledge and provided room to include other types of knowledge contributing to the multifunctional design.

\section{Conclusions}

GFP is a new and promising approach in flood protection management. Yet it seems that critical issues, such as the role of knowledge in decision-making and implementation, are overlooked. GFP is inherently uncertain, introduces dynamics and unpredictability, and is multifunctional. This will affect processes of knowledge production. Our study focused on understanding the role of knowledge processes in developing and decision-making GFP, by applying an analytical framework of 'interacting knowledge arrangements'. The analytical concept of knowledge arrangements is a way to analyse 'WoKs' by emphasizing interactions between science and policy domains as opposed to focusing on general science and policy interactions.

As a presupposition we argued that an integrated knowledge arrangement was needed to enable GFP. The case study Pilot Sand Engine Delfland confirmed this presupposition and provided detailed insights on the nature of such integration and impact on GFP decision-making. The merit of the integrated knowledge arrangement was in the development of integrated designs that were supported by a wide actor coalition. Important in this respect were the multiple project objectives, the broad actor coalition and power levelling mechanisms. Flexibility of the integrated knowledge arrangement was central to the effectiveness of the integration. Flexibility was found in the interpretation of objectives and actor coalitions providing ample space for designing. Together with the exclusion of core values from the foundational arrangements in the integrated knowledge arrangement, conflicts and discussion were prevented and decision-making could proceed in a fluent manner. The project had become a low-risk exercise with little at stake. The case study provided insights in the factors enabling integration and the consequences for GFP decision-making. However, it did not yet yield insights in the interaction processes among domains. Application to other cases - with more interaction processes visible-is therefore recommended.

A more general insight from the case study points to the difficulties of implementing GFP in everyday flood protection institutions and routines, at least for the Dutch context. It appears that GFP is only possible when positioned outside the daily routines. Both the multifunctionality and the uncertainty related to GFP are difficult to combine in the current construction of the flood protection knowledge arrangement, which is traditionally focused on effective coastline maintenance. However, this pilot project provides an important experience with realizing GFP as trust and confidence was built with an innovative approach. Moreover, it should not be regarded as only a physical experiment as it serves in a similar way as a 'field laboratory' for institutional innovation (Renting \& Van Der Ploeg, 2001). The know-how and trust gained might affect future developments in (Dutch) flood protection projects in a positive way. Given the temporary nature of the Sand Engine, the challenge of knowledge transfer to more permanent 
governance structures becomes a matter of interest (Sjöblom, 2009). Another advantage is that the project attracts visitors from all over the world and serves as an international eye-catcher of innovative Dutch flood protection (and its industry).

This case study provides an example of how boundary integration was enabled by excluding some elements. The annual budget for coastline maintenance and the BKL objective (core values), for instance, were not part of the integration. Literature on boundary work has a focus on linkages across boundaries by, among others, boundary organizations, objects, experiences or other boundary design elements (Dewulf et al., 2013; Guston, 2001; Leith et al., 2014). We suggest that explorations of boundary management should include a focus on the exclusion of certain linkages, as it may provide a key to establishing an effective boundary.

\section{Acknowledgements}

The authors thank the respondents for the interviews and the project team of the project Pilot Sand Engine Delfland. The authors thank the three anonymous reviewers for their valuable comments on an earlier version of this paper.

\section{Funding}

The research was enabled by financial support of Ecoshape (GOV4.1-project no. 352004).

\section{Notes}

1. A variety of terms have been used to more or less the same ideas of more green forms of protection against flooding. For example, we found: ecosystem-based management (Barbier et al., 2008) or adaptation (Hale et al., 2009), ecological engineering (Cheong et al., 2013; Mitsch, 2012), building with nature (De Vriend et al., 2014; Van Slobbe et al., 2013), ecological enhancement (Naylor et al., 2012) or nature-based flood defence (Van Wesenbeeck et al., 2014).

2. Defined by Mitsch and Jørgensen (2003, p. 369) as 'the property of systems in general to reorganize themselves given an environment that is inherently unstable and non-homogeneous'.

3. The authors of the Ways of Knowing concept are fully aware of this: 'we come to this writing with only a rough idea of what a way of knowing is and what it is not' (Feldman \& Ingram, 2009, p. 124). Muñoz-Erickson (2013) did empirical research into 'knowledge action systems'. She based her analysis on a network analysis, which provides evidence of the existence of these systems, but does not include the dynamics inherent in ways of knowing.

4. Recreation was also one of the objectives, for which a knowledge arrangement could have been identified. Given our focus on GFP, we restricted the analysis to the interactions among the nature and flood protection knowledge arrangements.

5. RWS is an executive directorate of the ministry responsible for water management. This Ministry of Transport, Public Works and Water Management (in Dutch Ministerie van Verkeer en Waterstaat, V\&W) merged in 2010 with the Ministry of Housing, Spatial Planning and the Environment (VROM) into a new Ministry of Infrastructure and Environment (I\&M).

6. Flood protection strategy comprises the maintenance of the coastline and the water defence (dunes or hard structures). These two are separate entities and organizationally split.

7. Involvement differs among regions. For an overview, see Donkers and Jacobs (2005).

8. A European network of nature protected areas under the Birds and Habitats directives.

9. The Sand Engine could possibly affect the Natura2000 site Solleveld and Kapittelduinen and the protected natural reserve Solleveld. In such cases law prescribes an 'appropriate assessment'. If the assessment outcome indicates significant negative impacts, mitigation, considering alternatives or compensation is required. For the Sand Engine, the appropriate assessment showed possible impact on Solleveld, which could be mitigated by means of management measures. 


\section{References}

Abma, R., \& Berkers, R. F. A. (2006). Tekorten aan recreatieruimte in de Zuidvleugel. Input voor programma's voor uitbreiding Delflandse kust (Eindrapportage).

AdviescommissievoordeZuid-Hollandsekust. (2006). Kustboekje Groeien naar kwaliteit. Den Haag.

Airoldi, L., Abbiati, M., Beck, M. W., Hawkins, S. J., Jonsson, P. R., Martin, D., .. , Åberg, P. (2005). An ecological perspective on the deployment and design of low-crested and other hard coastal defence structures. Coastal Engineering, 52(10-11), 1073-1087.

Barbier, E. B., Koch, E. W., Silliman, B. R., Hacker, S. D., Wolanski, E., Primavera, J., ..., Reed, D. J. (2008). Coastal ecosystem-based management with nonlinear ecological functions and values. Science, 319(5861), 321-323.

Bogaert, D., \& Gersie, J. (2006). High noon in the low countries: Recent nature policy dynamics in the Netherlands and in flanders. In B. Arts \& P. Leroy (Eds.), Institutional dynamics in environmental governance (pp. 115-138). Dordrecht: Springer.

Bremer, S., \& Glavovic, B. (2013). Exploring the science-policy interface for integrated coastal management in New Zealand. Ocean and Coastal Management, 84, 107-118.

Brugnach, M., \& Ingram, H. (2012). Ambiguity: The challenge of knowing and deciding together. Environmental Science and Policy, 15(1), 60-71.

Caplan, N. (1979). The two communities theory and knowledge utilization. American Behavioural Scientist, 22(3), 459-470.

Cash, D. W., Clark, W. C., Alcock, F., Dickson, N. M., Eckley, N., Guston, D. H., ..., Mitchell, R. B. (2003). Knowledge systems for sustainable development. Proceedings of the National Academy of Sciences of the United States of America, 100(14), 8086-8091.

Cheong, S. M., Silliman, B., Wong, P. P., Van Wesenbeeck, B., Kim, C. K., \& Guannel, G. (2013). Coastal adaptation with ecological engineering. Nature Climate Change, 3(9), 787-791.

Coffey, B., \& O'Toole, K. (2012). Towards an improved understanding of knowledge dynamics in integrated coastal zone management: A knowledge systems framework. Conservation and Society, 10(4), $318-329$.

Deltacommissie. (2008). Samen werken met water. Een land dat leeft, bouwt aan zijn toekomst. Bevindingen van de Deltacommissie 2008.

Derkzen, P., Bock, B. B., \& Wiskerke, J. S. C. (2009). Integrated rural policy in context: A case study on the meaning of 'integration' and the politics of 'sectoring'. Journal of Environmental Policy E Planning, 11(2), 143-163. doi:10.1080/15239080902920126

De Vriend, H. J., van Koningsveld, M., \& Aarninkhof, S. (2014). 'Building with nature': The new Dutch approach to coastal and river works. Proceedings of the Institution of Civil Engineers, 167(CE1), 18-24.

Dewulf, A., Brugnach, M., Termeer, C., \& Ingram, H. (2013). Bridging knowledge frames and networks in climate and water governance. In J. Edelenbos, N. E. W. Bressers, \& P. H. T. Scholten (Eds.), Water governance as connective capacity (pp. 229-247). Farnham: Ashgate.

Donkers, M., \& Jacobs, C. E. J. (2005). Inzicht in de huidige werkwijze bij het opstellen van het suppletieschema. Arnhem: Definitief.

Edelenbos, J., Van Buuren, M. W., \& Van Schie, N. (2011). Co-producing knowledge: Joint knowledge production between experts, bureaucrats and stakeholders in Dutch water management projects. Environmental Science and Policy, 14(6), 675-684.

Feldman, D. L., \& Ingram, H. M. (2009). Making science useful to decision makers: Climate forecasts, water management, and knowledge networks. Weather, Climate, and Society, 1(1), 9-21.

Feldman, M. S., Khademian, A. M., Ingram, H., \& Schneider, A. L. (2006). Ways of knowing and inclusive management practices. Public Administration Review, 66(Suppl. 1), 89-99.

Gedan, K. B., Kirwan, M. L., Wolanski, E., Barbier, E. B., \& Silliman, B. R. (2011). The present and future role of coastal wetland vegetation in protecting shorelines: Answering recent challenges to the paradigm. Climatic Change, 106(1), 7-29.

Gerritsen, A. L., Kamphorst, D. A., Selnes, T. A., Van Veen, M., Van den Bosch, F. J. P., Van den Broek, L., ..., Van der Wielen, P. (2009). Dilemma's en barrières in de praktijk van het natuur-en landschapsbeleid. Achtergronddocument bij Natuurbalans 2009. Wageningen. Retrieved from WOT Natuur \& Milieu.

Giardino, A., Mulder, J., Ronde, J. D., \& Stronkhorst, J. (2011). Sustainable development of the Dutch coast: Present and future. Journal of Coastal Research (Special Issue 61), 166-172.

Giebels, D., van Buuren, M. W., \& Edelenbos, J. (2013). Ecosystem-based management in the Wadden Sea: Principles for the governance of knowledge. Journal of Sea Research, 82, 176-187.

Gieryn, T. F. (1983). Boundary-work and the demarcation of science from non-science: Strains and interests in professional ideologies of scientists. American Sociological Review, 48(6), 781-795. 
Gray, B. (2004). Strong opposition: Frame-based resistance to collaboration. Journal of Community and Applied Social Psychology, 14(3), 166-176.

Guston, D. H. (2001). Boundary organizations in environmental policy and science: An introduction. Science, Technology, E Human Values, 26(4), 399-408. doi:10.2307/690161

Hale, L. Z., Meliane, I., Davidson, S., Sandwith, T., Beck, M., Hoekstra, J., ..., Marshall, P. (2009). Ecosystem-based adaptation in marine and coastal ecosystems. Renewable Resources Journal, 25(4), 21-28.

Halpern, B. S., McLeod, K. L., Rosenberg, A. A., \& Crowder, L. B. (2008). Managing for cumulative impacts in ecosystem-based management through ocean zoning. Ocean $\mathcal{E}$ Coastal Management, 51(3), 203-211. doi:10.1016/j.ocecoaman.2007.08.002

Hommes, S. (2008). Conquering complexity, dealing with uncertainty and ambiguity in water management (PhD thesis). University of Twente, The Netherlands.

Hommes, S., Vinke-de Kruijf, J., Otter, H. S., \& Bouma, G. (2009). Knowledge and perceptions in participatory policy processes: Lessons from the delta-region in the Netherlands. Water Resources Management, 23(8), 1641-1663.

Huitema, D., \& Meijerink, S. (2010). Realizing water transitions: The role of policy entrepreneurs in water policy change. Ecology and Society, 15(2).

Janssen, S. K. H., Mol, A. P. J., Van Tatenhove, J. P. M., \& Otter, H. S. (2014). The role of knowledge in greening flood protection. Lessons from the Dutch case study future Afsluitdijk. Ocean E Coastal Management, 95, 219-232. doi:10.1016/j.ocecoaman.2014.04.015

Jasanoff, S. (2004). States of knowledge: The co-production of science and social order. London: Routledge.

Katsanevakis, S., Stelzenmüller, V., South, A., Sørensen, T. K., Jones, P. J. S., Kerr, S., ... , Hofstede, R. T. (2011). Ecosystem-based marine spatial management: Review of concepts, policies, tools, and critical issues. Ocean and Coastal Management, 54(11), 807-820.

Koskinen, K. U., Pihlanto, P., \& Vanharanta, H. (2003). Tacit knowledge acquisition and sharing in a project work context. International Journal of Project Management, 21(4), 281-290.

Leith, P., O'Toole, K., Haward, M., Coffey, B., Rees, C., \& Ogier, E. (2014). Analysis of operating environments: A diagnostic model for linking science, society and policy for sustainability. Environmental Science and Policy, 39, 162-171.

Lejano, R. P., \& Ingram, H. (2009). Collaborative networks and new ways of knowing. Environmental Science and Policy, 12(6), 653-662.

Liefferink, D. (2006). The dynamics of policy arrangements: Turning round the tetrahedron. In B. Arts \& P. Leroy (Eds.), Institutional dynamics in environmental governance (pp. 45-68). Dordrecht: Springer.

Lubbers, B., De Heer, J., Groenendijk, J., Van Bockel, M., Blekemolen, M., Lambeek, J., \& Steijn, R. (2007). Evaluatie Derde Kustnota. In opdracht van het Ministerie van Verkeer en Waterstaat (Report No. 457108/ BLU/HMU). Amersfoort.

McNie, E. C. (2007). Reconciling the supply of scientific information with user demands: An analysis of the problem and review of the literature. Environmental Science and Policy, 10(1), 17-38.

Mitsch, W. J. (2012). What is ecological engineering? Ecological Engineering, 45, 5-12.

Mitsch, W. J., \& Jørgensen, S. E. (2003). Ecological engineering: A field whose time has come. Ecological Engineering, 20(5), 363-377. doi:10.1016/j.ecoleng.2003.05.001

Mulder, J. P. M., Hommes, S., \& Horstman, E. M. (2011). Implementation of coastal erosion management in the Netherlands. Ocean and Coastal Management, 54(12), 888-897.

Muñoz-Erickson, T. A. (2013). Co-production of knowledge-action systems in urban sustainable governance: The KASA approach. Environmental Science and Policy, 37, 182-191.

Naylor, L. A., Coombes, M. A., Venn, O., Roast, S. D., \& Thompson, R. C. (2012). Facilitating ecological enhancement of coastal infrastructure: The role of policy, people and planning. Environmental Science and Policy, 22, 36-46.

Nursey-Bray, M. J., Vince, J., Scott, M., Haward, M., O’Toole, K., Smith, T., . . , Clarke, B. (2014). Science into policy? Discourse, coastal management and knowledge. Environmental Science and Policy, 38, 107-119.

Odum, H. T., \& Odum, B. (2003). Concepts and methods of ecological engineering. Ecological Engineering, 20(5), 339-361.

O'Toole, K., \& Coffey, B. (2013). Exploring the knowledge dynamics associated with coastal adaptation planning. Coastal Management, 41(6), 561-575.

PZH. (2009). Informatieavond pilot Zandmotor 29 januari en 3 februari 2009.

PZH. (2010). Projectnota/MER Zandmotor Delflandse kust.

PZH \& RWS. (2014). De Zandmotor. Retrieved August 11, 2014, from www.dezandmotor.nl 
Renting, H., \& Van Der Ploeg, J. D. (2001). Reconnecting nature, farming and society: Environmental cooperatives in the Netherlands as institutional arrangements for creating coherence. Journal of Environmental Policy E Planning, 3(2), 85-101. doi:10.1002/jepp.75

Röling, N. (1992). The emergence of knowledge systems thinking: A changing perception of relationships among innovation, knowledge process and configuration. Knowledge and Policy, 5(1), 42-64.

RWS. (2005). Rapportage verkenningsfase Project Zand en Ze(e)ker (de "zandmotor" bij Ter Heijde). Den Haag.

Schneider, A. L., \& Ingram, H. (2007). Ways of knowing: Implications for public policy. Annual meeting of the American Political Science Association, Chicago, IL.

Sjöblom, S. (2009). Administrative short-termism-A non-issue in environmental and regional governance. Journal of Environmental Policy and Planning, 11(3), 165-168.

Smits, A. J. M., Nienhuis, P. H., \& Saeijs, H. L. F. (2006). Changing estuaries, changing views. Hydrobiologia, 565(1 Special Issus), 339-355.

Spalding, M. D., Ruffo, S., Lacambra, C., Meliane, I., Hale, L. Z., Shepard, C. C., \& Beck, M. W. (2013). The role of ecosystems in coastal protection: Adapting to climate change and coastal hazards. Ocean and Coastal Management, 90, 50-57.

Stive, M. J. F., De Schipper, M. A., Luijendijk, A. P., Aarninkhof, S. G. J., Van Gelder-Maas, C., Van Thiel De Vries, J. S. M., ... , Ranasinghe, R. (2013). A new alternative to saving our beaches from sea-level rise: The sand engine. Journal of Coastal Research, 29(5), 1001-1008.

Temmerman, S., Meire, P., Bouma, T. J., Herman, P. M. J., Ysebaert, T., \& De Vriend, H. J. (2013). Ecosystem-based coastal defence in the face of global change. Nature, 504(7478), 79-83.

Turnhout, E., Hisschemöller, M., \& Eijsackers, H. (2007). Ecological indicators: Between the two fires of science and policy. Ecological Indicators, 7(2), 215-228.

Van Buuren, M. W. (2009). Knowledge for governance, governance of knowledge: Inclusive knowledge management in collaborative governance processes. International Public Management Journal, 12(2), $208-235$.

Van Buuren, M. W., De Bruin, E., Zweegman, G.-J., Becker, L., \& Raadgever, T. (2010). Strategieën voor integrale kustontwikkeling in een versnipperd institutioneel systeem. Zoetermeer.

Van Buuren, M. W., \& Edelenbos, J. (2004). Why is joint knowledge production such a problem? Science and Public Policy, 31(4), 289-299.

Van de Riet, A. W. T. (2003). Policy analysis in multi-actor policy settings: Navigating between negotiated nonsense and superfluous knowledge. Technische Universiteit Delft: Eburon Publishers.

Van den Hoek, R. E., Brugnach, M., \& Hoekstra, A. Y. (2012). Shifting to ecological engineering in flood management: Introducing new uncertainties in the development of a Building with Nature pilot project. Environmental Science and Policy, 22, 85-99.

Van Kerkhoff, L. (2005). Integrated research: Concepts of connection in environmental science and policy. Environmental Science and Policy, 8(5), 452-463.

Van Kerkhoff, L., \& Lebel, L. (2006). Linking knowledge and action for sustainable development. Annual Review of Environment and Resources, 31(1), 445-477.

Van Koningsveld, M., \& Mulder, J. P. M. (2004). Sustainable coastal policy developments in the Netherlands. A systematic approach revealed. Journal of Coastal Research, 20(2), 375-385.

Van Slobbe, E., De Vriend, H. J., Aarninkhof, S., Lulofs, K., De Vries, M., \& Dircke, P. (2013). Building with nature: In search of resilient storm surge protection strategies. Natural Hazards, 65(1), 947-966.

Van Tatenhove, J. P. M., Arts, B., \& Leroy, P. (Eds.). (2000). Political modernisation and the environment. The renewal of environmental policy arrangements. Dordrecht: Kluwer Academic Publishers.

V\&W. (1990). Eerste kustnota: kustverdediging na 1990. Den Haag, The Netherlands.

V\&W. (2000). 3e Kustnota, Traditie, Trends en Toekomst. Den Haag.

V\&W. (2007). De Watervisie Nederland veroveren op de toekomst. Den Haag.

Van Wesenbeeck, B. K., Griffin, J. N., Van Koningsveld, M., Gedan, K. B., McCoy, M. W., \& Silliman, B. R. (2013). Nature-based coastal defenses: Can biodiversity help? In S. Levin (Ed.), Encyclopedia of biodiversity (2nd ed., 451-458). Waltham, MA: Academic Press.

Van Wesenbeeck, B. K., Mulder, J. P. M., Marchand, M., Reed, D. J., de Vries, M. B., de Vriend, H. J., \& Herman, P. M. J. (2014). Damming deltas: A practice of the past? Towards nature-based flood defenses. Estuarine, Coastal and Shelf Science, 140, 1-6. doi:10.1016/j.ecss.2013.12.031

Vikolainen, V., Bressers, H., \& Lulofs, K. (2013). The role of Natura 2000 and project design in implementing flood defence projects in the Scheldt estuary. Journal of Environmental Planning and Management, 56(9), 1359-1379.

Vinke-De Kruijf, J., Hulscher, S. J. M. H., \& Bressers, J. T. A. (2013). Knowledge transfer in international cooperation projects: Experiences from a Dutch-Romanian project. Floods: From Risk to Opportunity, $357,423-434$. 
Vreugdenhil, H., Slinger, J., Thissen, W., \& Rault, P. K. (2010). Pilot projects in water management. Ecology and Society, 15(3).

Wiering, M., Crabbe, A., Leroy, P., \& Arts, B. (2001). Kennis voor beleid natuurlijk. Onderzoeksproject stroomlijning van het wetenschappelijk natuuronderzoek in Vlaanderen.

\section{Appendix. Overview of interviews}

Table A1. Overview of interviews for the Sand Engine case study

\begin{tabular}{lll}
\hline Organization & \multicolumn{1}{c}{ Position respondent } & Interview date \\
\hline Deltares & $\begin{array}{l}\text { Researcher (also involved with Sand Engine } \\
\text { as a former employee of RWS) }\end{array}$ & 5 October 2009 \\
DGW & Coordinator coastal policy, part of project team since 2008 & \\
Consultant & Advisor project team Sand Engine & 10 February 2010 \\
PZH & Project manager Sand Engine & 10 February 2010 \\
Consultant & Principle researcher consultant for EIA development & 16 February 2010 \\
RWS & Two respondents: representative in core team Sand & 17 February 2010 \\
& $\quad$ Engine and RWS coordinator of the Sand Engine project & 11 March 2010 \\
RWS & Senior advisor flood protection & 17 March 2010 \\
Deltares & Researcher (also involved with Sand Engine as a & 19 April 2010 \\
& $\quad$ former employee of RWS) & 23 April 2010 \\
Deltares & Researcher & 28 April 2010 \\
RWS & Coordinator EIA content & 22 June 2011 \\
Consultant & Ecologist & 10 August 2011 \\
Consultant & Ecologist & 15 August 2011 \\
PZH & Member project team Nature and Recreation & \\
\hline
\end{tabular}

